\title{
Toward a Different Type of Education
}

\author{
David Fernández Dávalos
}

\section{The Diagnosis}

Like Ernesto Sabato said in his last book La Resistencia, we must urgently address the need to reinvent, to bolster, to develop a different type of education. It must be rooted in the conviction that only spiritual values can save us from the tremor that is threatening human existence. Indeed, we most certainly find ourselves facing the most serious crossroads in the history of humankind. Pope Francis has said as much in his encyclical Laudato Si': we cannot continue to move in the same direction as we have been. The humanism that has characterized Western thought since its inception has been undermined by overwhelming skepticism and has even been expelled by attacks from the economic productive rationality that is levelling everything in its path. Faith in human beings and in the forces that sustained us has been broken in the heart of humanity. "The first tragedy that must urgently be repaired," says the Argentine writer, "is the devaluation of oneself which man feels, and which adapts the previous steps to submission and massification. Today, man does not feel himself a sinner, he thinks he is a mechanism, which is tragically worse." (Sabato 2000:125126)

Human freedom is thus seriously threatened. And without freedom, human existence is worthless, because it is what has been given to us so that we can fulfil our mission in life.

Today, in this new century of integrated humanity, education has been taken over by the market. It is no longer, like in days gone by, the instrument to fight against submission and ignorance but is something to be acquired and possessed, with production costs and an exchange value.

There is then a tendency to look upon resources allotted by the state for education, not as an act of justice or compliance with a public duty, but rather as an expense,

D. Fernández Dávalos (凶)

Universidad Iberoamericana Mexico City, Mexico City, Mexico

e-mail: david.fernandez@ibero.mx

(C) The Author(s) 2021

H. van't Land et al. (eds.), The Promise of Higher Education,

https://doi.org/10.1007/978-3-030-67245-4_63 
an investment, or subsidy. The right to education has become a right to avail of education services, and this, in turn, has made students become clients at schools. The project of forming free, autonomous subjects has turned into the production of human resources, and the old evaluation criteria have become quality standards. Citizens have thus become the demand-side and clients of education services, just as they are the demand-side or clients of water or electricity services (Rodríguez 2000). In globalization, there are no more citizens; there are only consumers, potential clients who demand services.

Once education is conceived as a benefit, and when the justice of benefits is advocated for rather than the principles of justice, then free education becomes irrational and morally inadmissible. "In the logic of benefit," he writes, "the enemy to beat is not the right to education; its dark beast is its free nature." (Rodríguez 2000: 107-108)

I am convinced that the strengthening of our democracies depends greatly on actions taken to reduce inequality, particularly in the education system, and a turn toward the formation of fully democratic, solidary, participatory, and enlightened citizens.

\section{Jesuit Universities in Mexico's Moment}

The Jesuit university system right now is barely at the threshold of what I believe will be the key aspect of the new university model we strive for. I am referring specifically to a review of the curriculum.

To explain, I will closely follow in this section the notes systemized by Luna (2001). The main points to be covered in this process and which, in my opinion, every humanistic education should aspire for in this century are explained below.

(a) The preparation for a life in which a socially useful profession is practiced This goal goes far beyond the technical and disciplinary aspects of professional training in a strict sense. It can also be seen in the notion of "comprehensive formation", coherent with a vision of human beings that recognizes their many complex dimensions and dynamics and is committed to them based on this complexity.

Concretely, the formation we offer should cover work preparation, social formation, ethical training, expressive-cultural formation, collaborative training, preparation for uncertainty and change, preparation for permanent learning, ecological training, and formation for transcendence.

(b) The socio-professional target: Between the job market and the social project Of the series of learning aspects, preparing for work is what gives university programs their specific identity and sets the curriculum. This identity is built based on a socio-professional target. Defining a socio-professional target always compares job-market facts against the social project backed by the university. This contradiction needs to be reconciled. If what we seek is to contribute to building a more just, more humane society, we must bet on socio-professional targets 
where, even if only hypothetically, the university's contribution to this quest is visible. Therefore, we do not seek to separate the market from the university's values but rather to build a socially pertinent educational plan. To be pertinent, it must be based on the reality of the systematic analysis of professional market conditions, yet able to recognize this reality's diversity and impetus and be based on the possibilities of university action, like coherent options that seek to transform.

(c) The socio-professional target: Between specialization and general education Knowledge expansion has occurred hand-in-hand with growing specialization. Scientific and technological development has been responsible for the fragmentation of knowledge and the difficulty in recognizing how knowledge can be applied. To deal with this situation, our universities plan to include elements that precisely promote and address the criticism of knowledge, as well as the search for an articulated understanding of reality in its many facets-not a fragmented one. Furthermore, universities should also opt to work on the notion of professional families instead of the traditional idea of a profession as a definitive, excluding reality, and to provide students with the necessary know-how to face the changing work arena with flexibility.

Our work hypothesis is mainly one of recognition and formulation of this strategic know-how, meaning a better ability to sustain desirable professional achievements and to create educational options and specific learning objectives in classroom programs.

In any case, since professions and knowledge are now socially dynamic, the tension between general education and specialization can only be met by making "learning to learn" a key point of our university's teaching plan.

\section{(d) Learning focused on subjects and their processes}

Although we have emphasized the idea that learning must be focused on the student, we have yet to appreciate what that really entails. One way would be to assume the premise that students learn based on their own activity linked to learning targets and not based on what others do with them, be it the professor or the institution. It means knowing what the students really are. It means focusing on what actions are implicit to the learning process and how these actions lead to the desired learning.

From this perspective, professors are not the focus, or even better, the professors' role in teaching interactions is reshaped: they become assistants, mediators, helpers, facilitators.

Thus, teaching is no longer considered a one-way act from professor to student, carried out through the transmission of information and in the verification that this information is adequately returned, but is rather a question of learning environments or situations. Education is the intentional bringing together of different aspects - content, actions, spaces, times, resources — with an intent or purpose, using a teaching strategy. 
(e) The attributes of learning In our conception, we refer to three desirable learning criteria or attributes: learning that is significant, situated, and geared toward achieving competencies. Carlos Luna, from the ITESO, has recreated this proposal, breaking it down into six attributes that should be goals for the permanent construction of teaching processes. They are as follows:

- Significant learning: When subjects link the new information with their field of experience, their learning projects, and their lives.

- Reflexive learning: When subjects are able to realize what they have learned, and which actions and interactions led to that learning.

- Situated learning: Contextualizing historically the goal and content and pitting the learning processes against concrete questions or problems in a context of reality to give pertinent, consistent responses.

- Action-based learning: It can be seen in observable, evaluable results to concrete, situated problems. Subjects learn by doing and evaluating the results.

- Collaborative learning: It means learning with others, an interdisciplinary approach to problems, and teamwork, but especially respect for differences and diversity.

- Transferable learning: Allow subjects to apply the knowledge acquired to several situations and to enhance it permanently each time it is applied. It is based on "learning how to learn."

The goal of all these measures is to achieve a comprehensive outlook on learning.

(f) Beyond the classroom The language, as I have presented it, reaches far beyond the classroom, and takes on a kind of ubiquity in dealing with several situations both within the university and outside of it. It means reconsidering the role of the classroom in the learning process and a new outlook on a class subject as a unit of the curriculum.

It means going from the notion of a subject as packaged, transmittable knowledge to one of a comprehensive learning experience carried out through different activities and situations presented methodologically-including professor lectures when called for-based on a learning target and purpose.

Only from this perspective is it possible to face the complexity and wealth of learning and to incorporate the situations, formats, and times that this complexity requires: at times a lecture, a discussion seminar, individual study, workshops for production, lab practice, fieldwork, team projects, shared leisure time, the recovery of what has been learned, etc.

\section{First Conclusion}

As we can see, these are ambitious, perhaps radical, principles and ideas. Once again, I quote Ernesto Sábato. "There is something unfailing and it is the conviction that only spiritual values can save us from this earthquake that threatens the human condition." That is the huge task that we are facing as educators. 
As Pablo Latapí (2001:54-55) mentions in one of his final articles:

Education without compassion is poor; it is poor if, carried away by the cult of rationality, it sees human existence as entirely intelligible and ignores its contradictions. It is poor if it strives for a self-sufficient leadership separate from others. It is poor if it does not accept that we are beings-at-the limit, at times triumphant but often losers.

Is it possible to have a university that educates and teaches differently?

Here, I present some of the reflections that Ignacio Ellacuría made in several writings, which deal less so with educational processes and programs and more with the role the university should play in society.

We should clarify that this assumption is based on:

- A university should stand out for how it affects historical reality, something prominently political.

- Those who are oppressed and excluded are the objectives of the university's outreach activity.

- University activity finds its outlet in cultural aspects: cultivating the national reality, being critically and creatively aware.

- The goal of university action is to change the unjust, exclusionary reality.

Circumstances might seem to suggest that the education and university model we strive for is impossible to build. Let us take a closer look at what these hindrances are:

- Universities are economically dependent, whether on tuition, private capital, or government subsidies. If the university is coherent with what it says, if it insists on its autonomy, financial resources may dry up.

- There is social and political resistance to the university changing and being critical; people who hold the power in question are always a threat to the university.

- Students are also resistant; they do not want to be troubled but only to learn a profession.

- Likewise, professors show resistance, usually more passively than actively, but most of them usually resist change and are afraid of the consequences of institutional options.

- The authorities at the university are also resistant. It is much more difficult to run an engaged university, a more aware student body.

- More recently, rankings and accreditations act as obstacles to an autonomous, critically-minded university. They tend to follow market rules, which are often not in line with the university mission we have defined here.

What real possibilities are there to build a different type of university?

Let us reiterate some of the points:

1. The university, as an instrument for forming professionals, is necessary to society.

Higher education is needed. It will always exist, regardless of our role in it or our will. 
We are here to neutralize the damage it could do to society. We are here to attempt to use it to bring about social change.

2. Even if we cannot achieve the ideal we are proposing; the university can at least work toward the following:

- Legitimize and support ideologically those striving for change.

- Help to lessen personal and professional resistance to change.

- Limit power cores.

- Offer analysis and public-policy proposals in all areas of reality.

- Help to combat fear of change.

3. Furthermore, in universities, the first steps can be taken toward building new institutions aligned with what we are trying to do, such as:

- Define a different university model outside of the norms imposed. A truly autonomous university with no conditions.

- Develop its non-profit nature. The idea of a university education as a public good and a human right.

- Analyse the most pressing national issues to make rigorous, substantial contributions.

- Offer an independent voice, beyond the economic and political interests of the ruling classes and sectors.

- Offer honest professionals who support change. Educate for justice, empathy, solidarity, commitment, and transformative action.

- At times serve as a voice for the voiceless. Or, if preferred, open a space for those sectors that have been denied a voice. Open spaces for the poor and excluded to make their voices heard.

- Help marginalized sectors with projects covering several topics and areas, such as psychology, law, architecture, design, health, business, engineering, etc.

- Develop different perspectives: Prove that it is possible to create processes, practices, and actions that point in a new direction against the outlook of the mainstream. These options should create a life of abundance.

The Company of Jesus believes that a different type of university is possible. It believes that the university itself contributes to the mission of service to faith and the promotion of justice. It recognizes the university's multiple determinations, its complexity, and it strives to achieve full autonomy.

\section{References}

Latapí Sarre, P. (15.07.2001). "Los triunfadores”, Proceso No. 1289, pp 54-55.

Luna, C. (2001), Revisión curricular, Documento de trabajo, Dirección General Académica del ITESO, borrador, septiembre. 
Rodríguez, P. G. (2000). "Mirar el presente", Revista Latinoamericana de Estudios Educativos. México, Vol XXX, No. 2, pp. 85-113.

Sabato, E. (2000). La resistencia, Argentina: Seix Barral.

David Fernández Dávalos S. J. is the former Rector of Universidad Iberoamericana Ciudad de Mexico (IBERO) (2014-2020). From 1990 to 1994, he worked as founder and director of the Movement for Supporting Working and Street Children (MATRACA), and from 1994 to 1998 he was Director of the Miguel Agustín Pro Juárez Center for Human Rights, A.C. From July of 1998 to January of 2002 he has also served as rector of the Technological Institute and of Studies Superiors of the Occident (University ITESO) in Guadalajara; and from 2008 to 2013 he was rector of the Universidad Iberoamericana Puebla.

Open Access This chapter is licensed under the terms of the Creative Commons Attribution 4.0 International License (http://creativecommons.org/licenses/by/4.0/), which permits use, sharing, adaptation, distribution and reproduction in any medium or format, as long as you give appropriate credit to the original author(s) and the source, provide a link to the Creative Commons license and indicate if changes were made.

The images or other third party material in this chapter are included in the chapter's Creative Commons license, unless indicated otherwise in a credit line to the material. If material is not included in the chapter's Creative Commons license and your intended use is not permitted by statutory regulation or exceeds the permitted use, you will need to obtain permission directly from the copyright holder. 